\title{
The Next Generation Nuclear Plant
}

\author{
January 2009
}
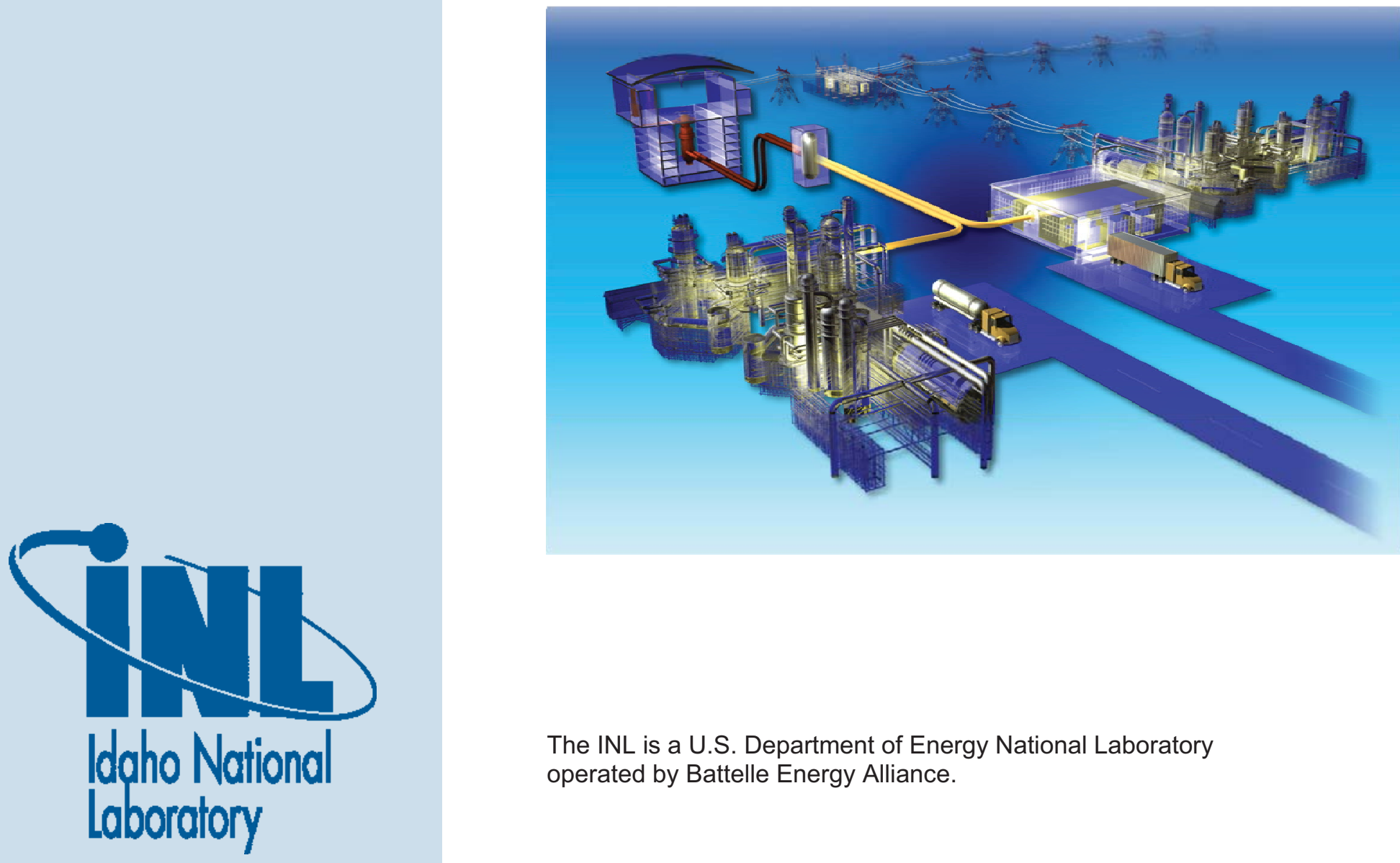

The INL is a U.S. Department of Energy National Laboratory operated by Battelle Energy Alliance. 


\section{DISCLAIMER}

This information was prepared as an account of work sponsored by an agency of the U.S. Government. Neither the U.S. Government nor any agency thereof, nor any of their employees, makes any warranty, expressed or implied, or assumes any legal liability or responsibility for the accuracy, completeness, or usefulness, of any information, apparatus, product, or process disclosed, or represents that its use would not infringe privately owned rights. References herein to any specific commercial product, process, or service by trade name, trade mark, manufacturer, or otherwise, does not necessarily constitute or imply its endorsement, recommendation, or favoring by the U.S. Government or any agency thereof. The views and opinions of authors expressed herein do not necessarily state or reflect those of the U.S. Government or any agency thereof. 


\section{The Next Generation Nuclear Plant}

January 2009

Idaho National Laboratory

Next Generation Nuclear Plant Project

Idaho Falls, Idaho 83415

Prepared for the

U.S. Department of Energy

Office of Nuclear Energy

Under DOE Idaho Operations Office

Contract DE-AC07-05ID14517 



\begin{abstract}
The Next Generation Nuclear Plant will be a demonstration of the technical, licensing, operational, and commercial viability of high temperature gas-cooled reactor (HTGR) technology for the production of process heat, electricity, and hydrogen. This nuclear-based technology can provide high-temperature process heat (up to $950^{\circ} \mathrm{C}$ ) that can be used as a substitute for the burning of fossil fuels for a wide range of commercial applications. The substitution of the HTGR for burning fossil fuels conserves these hydrocarbon resources for other uses, reduces uncertainty in the cost and supply of natural gas and oil, and eliminates the emissions of greenhouse gases attendant with the burning of these fuels. The HTGR is a passively safe nuclear reactor concept with an easily understood safety basis that permits substantially reduced emergency planning requirements and improved siting flexibility compared to other nuclear technologies.
\end{abstract}




\section{CONTENTS}

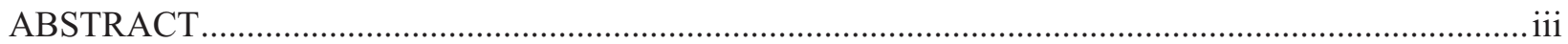

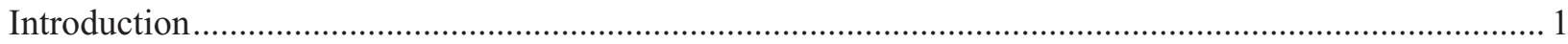

Preconceptual Design Team Recommendations for Plant Configuration, Operating Conditions

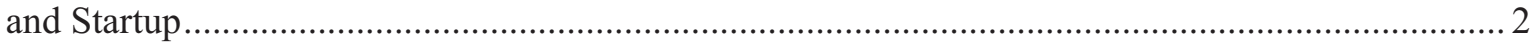

Key Development Risks and Associated Research and Development .................................................. 4

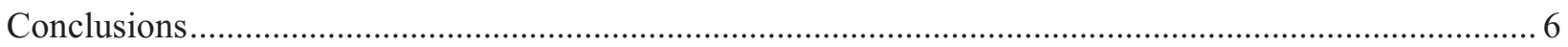

\section{FIGURES}

Figure 1. Range of temperatures required for HTGR process heat applications. ...................................... 1

Figure 2. Configurations of preconceptual NGNP designs................................................................... 2

\section{TABLES}

Table 1 Summary of preconceptual design operations and configurations. ............................................. 3 


\section{The Next Generation Nuclear Plant}

\section{Introduction}

The Next Generation Nuclear Plant (NGNP) will be a demonstration of the technical, licensing, operational, and commercial viability of high temperature gas-cooled reactor (HTGR) technology for the production of process heat, electricity, and hydrogen. This nuclear-based technology can provide hightemperature process heat (up to $950^{\circ} \mathrm{C}$ ) that can be used as a substitute for the burning of fossil fuels for a wide range of commercial applications (see Figure 1). The substitution of the HTGR for burning fossil fuels conserves these hydrocarbon resources for other uses, reduces uncertainty in the cost and supply of natural gas and oil, and eliminates the emissions of greenhouse gases attendant with the burning of these fuels. The HTGR is a passively ${ }^{\mathrm{a}}$ safe nuclear reactor concept with an easily understood safety basis that permits substantially reduced emergency planning requirements and improved siting flexibility compared to other nuclear technologies.

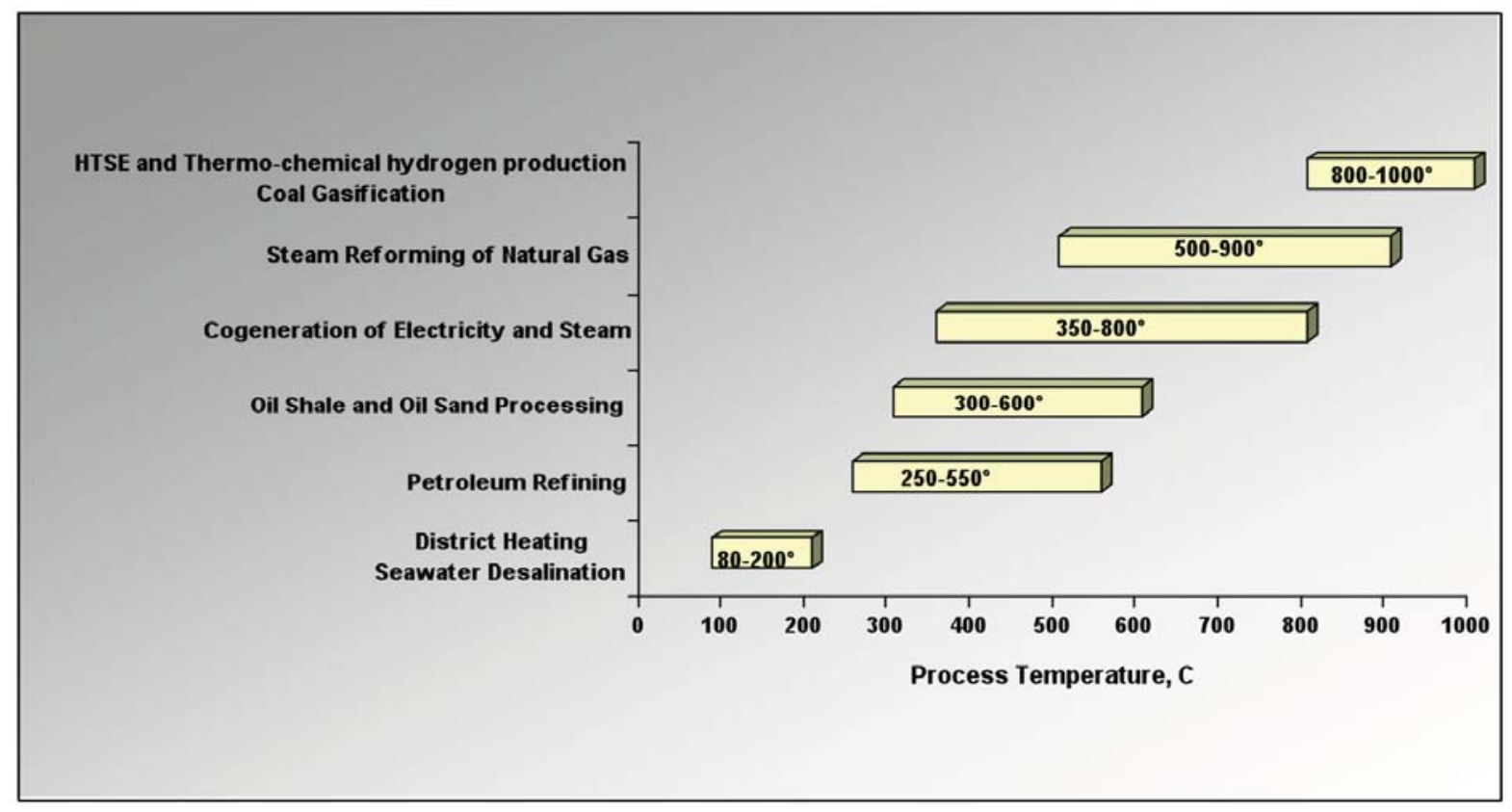

Figure 1. Range of temperatures required for HTGR process heat applications.

The Energy Policy Act of 2005 (EPAct) directed the U.S. Department of Energy (DOE) develop a demonstration of this HTGR technology to economically and reliably produce electricity and hydrogen by the year 2021. The EPAct also stipulated that the task should be undertaken in partnership with the industrial end users of the technology. To that end, a working group consisting of suppliers of the technology, nuclear plant owner/operators, other supportive technology companies, and potential end users was assembled. The objective of this working group is to form an Alliance that would provide the private sector perspective and direction for completion of the NGNP in partnership with the DOE. The Alliance will support the selection of the specific operating conditions and configuration for NGNP to ensure it meets private sector expectations, commence management of the project using commercial processes, share the cost of design and construction with the government, and secure a commercial

a. "Passive," as used here, means that the performance of engineered systems (e.g., the reactor cavity cooling system) are relied upon in the safety analyses, but without requiring any component in those systems to maintain or change state to satisfy the safety functions. 
nuclear operating company to operate the plant. Finally, as required by EPAct, the approach for licensing the NGNP is being developed through a joint effort between DOE and the U.S. Nuclear Regulatory Commission (NRC).

\section{Preconceptual Design Team Recommendations for Plant Configuration, Operating Conditions and Startup}

Three contractor teams with extensive experience in HTGR technology, nuclear power applications, and hydrogen production developed preconceptual designs for the NGNP Project. Westinghouse Electric Company, LLC, AREVA NP, Inc., and General Atomics were the leaders of each of the three teams. The objectives of the pre-conceptual design activities were to:

- Initiate development of the functional and operational requirements (F\&ORs)

- Establish a reference configuration of the NGNP

- Provide direction to the NGNP Project research and development (R\&D) programs to ensure they support design development, licensing, construction, and deployment of the NGNP

- Support development of the licensing strategy for the NGNP and, ultimately, development of a Certification of Design for the use of the HTGR technology in the private sector

- Develop preconceptual designs with sufficient detail to provide credible estimates of the schedule and costs for NGNP and an nth-of-a-kind plant

- Perform economic assessments for the nth-of-a-kind plant to confirm the economic viability of the HTGR technology in production of electricity and hydrogen.

Table 1 summarizes the key results of each contractor teams' evaluations and recommendations for the NGNP operating conditions and configuration. The Westinghouse team selected a $500 \mathrm{MWth}$ pebble bed reactor in an indirect cycle configuration that would produce power via a traditional rankine cycle and hydrogen via the hybrid-sulfur process in series. The AREVA team selected a $565 \mathrm{MWth}$ prismatic reactor in an indirect cycle configuration that would produce power via a Rankine cycle in parallel with hydrogen production via high temperature electrolysis in the near term and the sulfur iodine process in the longer term. The General Atomics team selected a 550 to $600 \mathrm{MWth}$ prismatic reactor in a direct cycle configuration to produce power with a Brayton cycle and via a small intermediate heat exchanger to produce hydrogen in parallel with power production. Schematics of these configurations are shown in Figure 2. Additional details of the configurations and operational parameters are shown in Table 1.
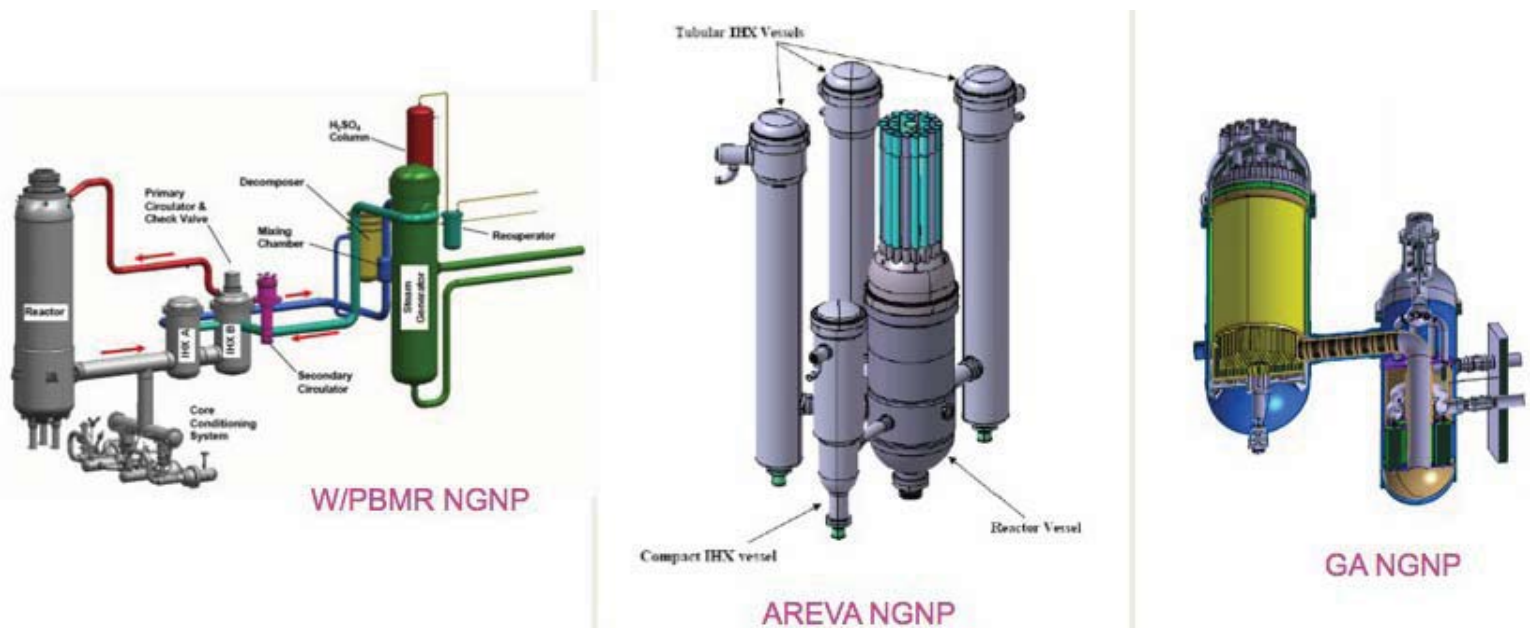

Figure 2. Configurations of preconceptual NGNP designs. 
Table 1 Summary of preconceptual design operations and configurations.

\begin{tabular}{|c|c|c|c|}
\hline \multirow[b]{2}{*}{ Item } & \multicolumn{3}{|c|}{ Recommended Operating Conditions \& Plant Configuration } \\
\hline & Westinghouse & AREVA & General Atomics \\
\hline Power Level, MWt & $500 \mathrm{MWt}$ & $565 \mathrm{MWt}$ & $550-600 \mathrm{MWt}$ \\
\hline Reactor Outlet Temperature, ${ }^{\circ} \mathrm{C}$ & $950^{\circ} \mathrm{C}$ & $900^{\circ} \mathrm{C}$ & Up to $950^{\circ} \mathrm{C}$ \\
\hline Reactor Inlet Temperature, ${ }^{\circ} \mathrm{C}$ & $350^{\circ} \mathrm{C}$ & $500^{\circ} \mathrm{C}$ & $490^{\circ} \mathrm{C}$ \\
\hline Cycle Configuration & $\begin{array}{l}\text { Indirect - Series hydrogen } \\
\text { process and power } \\
\text { conversion }\end{array}$ & $\begin{array}{l}\text { Indirect - Parallel hydrogen } \\
\text { process and power } \\
\text { conversion }\end{array}$ & $\begin{array}{l}\text { Direct PCS } \\
\text { Parallel indirect hydrogen } \\
\text { process }\end{array}$ \\
\hline Secondary Fluid & $\mathrm{He}$ & $\begin{array}{l}\text { He-Nitrogen to PCS } \\
\text { He to H2 Process }\end{array}$ & $\mathrm{He}$ \\
\hline Power Conversion Power & $100 \%$ of reactor power & $100 \%$ of reactor power & $100 \%$ of Reactor Power \\
\hline Hydrogen Plant Power & $10 \%$ of reactor power & $10 \%$ of reactor power & $\begin{array}{l}5 \mathrm{MWt}-\mathrm{HTE} \\
60 \mathrm{MWt}-\mathrm{S}-\mathrm{I}\end{array}$ \\
\hline Reactor Core Design & Pebble Bed & Prismatic & Prismatic \\
\hline Fuel & $\begin{array}{l}\text { TRISO UO2 1st and } \\
\text { subsequent cores }\end{array}$ & $\begin{array}{l}\text { TRISO UCO - 1st and } \\
\text { subsequent cores }\end{array}$ & $\begin{array}{l}\text { TRISO UO2 1st Core } \\
\text { Variable subsequent cores }\end{array}$ \\
\hline Graphite & PCEA \& NBG-18 & NGG-17 and NBG-18 & IG-110 \& NBG-18 \\
\hline RPV Design & $\begin{array}{l}\text { Exposed to the gas inlet } \\
\text { temperature }\end{array}$ & $\begin{array}{l}\text { Exposed to the gas inlet } \\
\text { temperature; insulation and } \\
\text { vessel cooling options may } \\
\text { be pursued }\end{array}$ & $\begin{array}{l}\text { Exposed to the gas inlet } \\
\text { temperature }\end{array}$ \\
\hline RPV Material & SA508/533 & $9 \mathrm{Cr}--1 \mathrm{Mo}$ & $\begin{array}{l}2-1 / 4 \mathrm{Cr}-1 \mathrm{Mo} \\
9 \mathrm{Cr}-1 \mathrm{Mo}\end{array}$ \\
\hline $\mathrm{IHX}$ & $\begin{array}{l}\text { 2- Stage Printed Circuit Heat } \\
\text { Exchanger (PCHE), In } 617 \\
\text { material }\end{array}$ & $\begin{array}{l}\text { PCS - } 3 \text { - Helical Coil Shell \& } \\
\text { Tube, In } 617 \\
\text { Process - PCHE or Fin-Plate, } \\
\text { In } 617\end{array}$ & $\begin{array}{l}\text { Process - single stage } \\
\text { PCHE, In } 617\end{array}$ \\
\hline Hydrogen Plant & $\begin{array}{l}\text { Hybrid thermo-chemical plus } \\
\text { electrolysis }\end{array}$ & $\begin{array}{l}\text { Initial -High Temperature } \\
\text { Electrolysis } \\
\text { Longer Term - Sulfur-lodine }\end{array}$ & $\begin{array}{l}\text { Initial -High Temperature } \\
\text { Electrolysis } \\
\text { Longer Term - Sulfur-lodine }\end{array}$ \\
\hline Power Conversion & $\begin{array}{l}\text { Rankine; standard fossil } \\
\text { power turbine generator set }\end{array}$ & $\begin{array}{l}\text { Rankine; standard fossil } \\
\text { power turbine generator set }\end{array}$ & $\begin{array}{l}\text { Direct gas turbine } \\
\text { Option -- Direct Combined } \\
\text { Cycle }\end{array}$ \\
\hline
\end{tabular}

Because the NGNP is a prototype plant, it is likely that initial operation will start at less than full design conditions with a subsequent proof-of-principle operating period of two to three years. During this operating period, extensive instrumentation of the plant, in-service inspection, and postirradiation examination of components (e.g., fuel and ceramics), and special test rigs (e.g., material test coupons) will be used to verify design assumptions as plant operating conditions are gradually expanded to the full design point. These inspections and tests will validate operating procedures, plant steady state and transient operating characteristics, and other features of the plant, including steady state and transient interactions among the reactor core, the power conversion system, and the hydrogen production plant. This initial operating period will also demonstrate general technical performance and reliability of the primary and support structures, systems, and components (SSCs; e.g., refueling equipment). During this period, parallel efforts will also continue to extend qualification data for reactor fuel, core and internals ceramics, and high-temperature metallic materials to permit extended operation of these components. 
It is possible that the plant may need to be operated for an extended period (e.g., up to 10 years) at less than full objective gas outlet temperature $\left(950^{\circ} \mathrm{C}\right)$ because of lower temperature capabilities in the materials of the heat exchange and transport systems. If this were the case, the planning would be to continue to develop these components with full-temperature capabilities with the expectation that they could be in service no later than ten years after initial operation. To understand the impact of this possibility on the commercialization potential of the technology, brief reviews of the conditions required to support commercial applications were performed. These reviews showed that a majority of the commercial applications could be served with gas outlet temperatures lower than recommended by the contractor teams (e.g., steam production for oil sands recovery or co-generation requires less than $800^{\circ} \mathrm{C}$, see Figure 1). The impact on the plant performance would be slightly lower efficiency in power production (if a Brayton cycle or combined-cycle PCS were used) and in the hydrogen production process. The latter could still be demonstrated at near full efficiency with the use of supplementary electric heating.

In summary, a ramp-up in the operating conditions of the NGNP prototype will likely be necessary and desirable to prove its principles of operation and, even if material limitations require an extended period until full temperature can be realized, this does not appear to compromise the commercialization objective of the prototype.

\section{Key Development Risks and Associated Research and Development}

The principal technical risks associated with the HTGR technologies anticipated for the NGNP include:

- Qualification and acquisition of reactor fuel (e.g., qualification of fuel production facilities); reactor core ceramics, including graphite and graphite production facilities; and metals in the hightemperature regions of the plant (e.g., in the reactor and heat transport system)

- Verification and validation of analysis methods required to support design development; American Society of Mechanical Engineers (ASME) code acceptance; American Society for Testing and Materials (ASTM) standards acceptance; and NRC licensing

- Availability of materials with acceptable metallurgical and physical properties in the required sizes and thicknesses and the ability to fabricate large vessels on-site using these materials

- Availability and development of instrumentation (e.g., to monitor the fluence, high temperatures, and gas flow rates in the plant)

- Development of the hydrogen production processes and components

- Potential contamination of the product streams and meeting acceptable limits of contamination

Research and development activities are planned in the areas of fuels, graphite, high temperature materials, design and safety methods, and heat transport to address these risks. Specifically:

- The Fuel Development and Qualification Program will qualify TRISO-coated particle fuel for use in NGNP. TRISO-coated particles will be fabricated at pilot scale for use in the formal qualification testing. The testing program consists of irradiations, safety testing and postirradiation examinations that will characterize the behavior of TRISO-coated fuel under both normal and off-normal conditions. The program also contains out-of-pile experiments, special irradiations and safety testing to characterize the release and transport of fission products from the kernel, through the coatings, the fuel matrix, the graphite and the primary system (i.e., source term). Formal validation testing is also planned to validate fuel performance and fission product models, required for core performance assessments and safety analysis. The program is currently considering both $\mathrm{UCO}$ and $\mathrm{UO}_{2}$. Once a

design decision is reached by the project, the program will focus on either $\mathrm{UCO}$ for prismatic or $\mathrm{UO}_{2}$ 
for pebble bed. Feasible acquisition strategies for fabrication of first core and qualification of the associated production scale fuel fabrication facility for both design concepts have been established and will be executed once the reactor design decision is made.

- The objective of the NGNP Graphite Program is to develop the qualification dataset of thermomechanical and thermophysical properties for unirradiated and irradiated candidate grades of graphite for NGNP. Where practical, other grades of graphite may be tested/characterized to provide a baseline for comparison or to help understand material property changes for the NGNP graphite grades. The program consists of statistical characterization of unirradiated graphite material properties to establish the lot-to-lot, billet-to-billet and within billet variability of the material. Irradiations are planned at specified temperatures and doses within the design service condition envelope anticipated for NGNP. Extensive postirradiation examinations are planned to establish the change in relevant material properties as a function of temperature and neutron dose. Of particular interest is the irradiation induced creep of graphite, which is critical to determining the lifetime of the graphite under irradiation. From these datasets, constitutive relations will be established for use in a detailed predictive thermo-mechanical finite element model. These data will also support development of relevant ASTM standards and ASME design rules. In the longer term, the program plans to evaluate processing route and raw material constituent influences on graphite behavior so that additional large qualification irradiation programs are not needed when new coke sources are used to make graphite for HTGRs.

- The goal of the High Temperature Materials Program for NGNP is to establish the relevant thermomechanical performance data to support the development of an intermediate heat exchanger and another high temperature components for an outlet temperature up to $950^{\circ} \mathrm{C}$. Creep, creepfatigue, aging, and environmental degradation testing is planned using the candidate high temperature material selected for NGNP. Thick and thin sections of base material, weldments and other joints (e.g. diffusion bonding) will be evaluated given the different design options under consideration for the intermediate heat exchanger. (Current candidates are inconel 617 and Haynes 230). Depending on the outlet temperature selected by the NGNP project, additional high temperature data may be needed to support relevant ASME code cases for the material. R\&D to establish requisite in-service inspection techniques will be developed as key components are being designed. Prototype testing of key components is envisioned in a high temperature flow loop to characterize overall behavior under prototypic flowing HTGR conditions and validate in-service inspection techniques.

- The goals of the Design and Safety Methods Validation Program for NGNP are to develop validation experiments and data to validate models and analytical tools for NGNP, to resolve key safety, performance, and technical issues through confirmatory modeling and/or tool development when existing models and/or tools are judged to be inconclusive or inadequate, and to modify, upgrade, and/or develop new analytical tools for future use that will reduce uncertainties and improve the capability of understanding the behavior and operating margins of the plant. Current areas of focus include developing improved differential cross-sections for plutonium isotopes to reduce uncertainties in the reactivity performance of high burnup low-enriched uranium HTGR cores, assessing and improving reactor physics and kinetic methods for prismatic and pebble bed HTGRs, performing physics benchmark studies on past relevant experiments, evaluating important phenomena that influence thermal-fluid behavior in HTGRs and establishing relevant experiments for $\mathrm{V} \& \mathrm{~V}$, evaluating of air-ingress phenomena in HTGRs and participating in relevant validation experiments, developing experiments to validate reactor cavity cooling system behavior, and evaluating and establishing system level codes appropriate for HTGR safety analysis.

The goal of Component Test Facility project is to design, construct, and startup a test facility to support development of high-temperature gas thermal-hydraulic technologies (e.g., helium, heliumnitrogen, $\mathrm{CO}_{2}$ ) as applied in heat transport and heat transfer applications in HTGRs. Such applications include but are not limited to primary coolant; secondary coolant; direct-cycle power conversion; 
intermediate, secondary and tertiary heat transfer; and demonstration of processes requiring high temperatures (e.g., hydrogen production, process heat demonstrations at large scale). The initial use of this facility will be in support of the completion of the NGNP. However, this test facility will be open for use by the full range of suppliers, end-users, facilitators, government laboratories, and others in the domestic and international community supporting the development and application of HTGR technology. The facility shall provide for full scale testing and qualification of high temperature fluid flow systems, components, and equipment (e.g., circulators, intermediate and tertiary heat exchangers, piping, and isolation valves) and associated instrumentation.

\section{Conclusions}

The NGNP Project will develop and demonstrate a first-of-a-kind very-high-temperature gas-cooled nuclear system with the capability to generate electrical power and produce process heat for hydrogen $\left(\mathrm{H}_{2}\right)$ production and other applications. The NGNP incorporates an inherently safe reactor concept with an easily understood safety basis that permits substantially reduced emergency planning requirements and improved siting flexibility compared to current and advanced light water reactors. The scope of the project includes development of a very-high-temperature gas-cooled nuclear system, alternative hydrogen production technologies that can efficiently use the process heat from the nuclear system, and power conversion technologies that promise important improvement in electrical power generating efficiencies.

The overall objectives of this project include:

- Developing and implementing the technologies required to achieve the functional performance and meet the design requirements determined through close collaboration with commercial industry endusers.

- Demonstrating the basis for commercialization of the nuclear system as a process heat source, the hydrogen production facility, and the power conversion concept. An essential part of the prototype operations will be demonstrating that the requisite reliability and capacity factor can be achieved over an extended period of operation.

- Establishing the basis for licensing the commercial version of NGNP by the NRC. This will be achieved in major part through licensing the prototype by NRC and initiating the process for certification of the nuclear process heat system design.

- Fostering rebuilding of the U.S. nuclear industrial infrastructure and contributing to making the U.S. industry self-sufficient for our nuclear energy production needs.

The project will be accomplished though the collaborative efforts of DOE and its national laboratories, commercial industry participants and international government agencies. The Idaho National Laboratory acting as the agent of DOE currently provides project management and technology development leadership for the project. 